\title{
Partial Purification and Characterization of
}

\section{a Peptide with Growth Hormone-releasing Activity from Extrapituitary Tumors in Patients with Acromegaly}

\author{
Lawrence A. Frohman, Marta Szabo, Michael Berelowitz, and \\ Max E. STaChura, Division of Endocrinology and Metabolism, \\ Department of Medicine, Michael Reese Medical Center and \\ University of Chicago, Chicago, Illinois 60616
}

A B S T R A C T Growth hormone (GH)-releasing activity has been detected in extracts of carcinoid and pancreatic islet tumors from three patients with $\mathrm{GH}$ secreting pituitary tumors and acromegaly. Bioactivity was demonstrated in $2 \mathrm{~N}$ acetic acid extracts of the tumors using dispersed rat adenohypophyseal cells in primary monolayer culture and a rat anterior pituitary perifusion system. The GH-releasing effect was dose responsive and the greatest activity was present in the pancreatic islet tumor. Small amounts of activity were also found in two other tumors (carcinoid and small cell carcinoma of lung) unassociated with GH hypersecretion.

Each of the tumors contained somatostatin-like immunoreactivity but the levels did not correlate with the net biologic expression of the tumor. Sephadex G-75 gel filtration indicated the GH-releasing activity to have an apparent molecular size of slightly greater than 6,000 daltons. The GH-releasing activity was adsorbed onto DEAE-cellulose at neutral $\mathrm{pH}$ and low ionic strength, from which it could be eluted by increasing ionic strength. The GH-releasing activity was further purified by high pressure liquid chromatography using an acetonitrile gradient on a cyanopropyl column to yield a preparation that was active at $40 \mathrm{ng}$ protein $/ \mathrm{ml}$. Partially purified GH-releasing activity, from which most of the bioactive somatostatin had been removed, increased GH release by pituitary monolayer cultures to five times base line. Enzymatic hydrolysis studies revealed that the GH-releasing activity was resistant to carboxypeptidase, leucineaminopeptidase, and pyroglutamate-amino-peptidase but was destroyed by trypsin and chymotrypsin, in-

Address reprint requests to Dr. Frohman.

Received for publication 4 June 1979 and in revised form 30 August 1979. dicating that internal lysine and/or arginine and aromatic amino acid residues are required for biologic activity and that the $\mathrm{NH}_{2}$-terminus and $\mathrm{COOH}$ terminus are either blocked or not essential.

The results provide an explanation for the presence of GH-secreting tumors in some patients with the multiple endocrine neoplasia syndrome, type I, and warrant the addition of GH-releasing activity to the growing list of hormones secreted by tumors of amine precursor uptake and decarboxylation cell types.

\section{INTRODUCTION}

The secretion of hormones by tumors arising from nonendocrine tissue or from endocrine tissue not normally secreting such hormones has been well established during the past two decades (1). The tumors involved have most frequently, though not exclusively, been bronchial adenomas of the carcinoid type, thymomas, pancreatic islet tumors, and small cell lung carcinomas (2-5). The hormones secreted are peptide and/or protein in nature and resemble the natural secretory products of the hypothalamus, pituitary, parathyroid glands, and pancreatic islets $(6-11)$.

The association of acromegaly and carcinoid tumors has also been recognized (12-16) and the presence of immunoreactive growth hormone $(\mathrm{GH})^{1}$ in a lung tumor has been demonstrated in one patient (15). Although ectopic production of $\mathrm{GH}$ could explain the presence of acromegaly, it could not be responsible for the development of a pituitary tumor. Recently, six patients with bronchial carcinoid- or pancreatic islet

'Abbreviations used in this paper: HPLC, high pressure liquid chromatography; GH, growth hormone, GHRF, GHreleasing factor; $\mathrm{PBS}$, phosphosaline buffer; pSME, porcine stalk median eminence; rGH, rat GH; SRIF-LI, somatostatinlike immunoreactivity. 
tumor-associated acromegaly have been reported in whom normal GH secretion has been restored and/or the clinical features of the disorder ameliorated after removal of the extrapituitary tumor without specific therapy directed to the hypothalamic-pituitary area $(15-18)$. We have reported that an extract of the bronchial carcinoid tumor removed from one of these patients stimulated the release of $\mathrm{GH}$ from dispersed rat anterior pituitary cells in primary monolayer culture (18) and have suggested that the pituitary tumor and acromegaly were secondary to secretion of a GH-releasing factor (GHRF) by the carcinoid tumor. The present report describes studies directed at purifying and characterizing the $\mathrm{GH}$-releasing activity present in extrapituitary tumors from patients with acromegaly.

\section{METHODS}

\section{Source of tumor tissue}

Tumor tissue from three patients with GH hypersecretion and extrapituitary tumors was made available for study:

Patient 1. Details of this patient's clinical course have been recently reported (18). Bronchial carcinoid tumor (250 $\mathrm{mg}$ ) frozen at the time of surgical excision $7 \mathrm{yr}$ previously was provided by Doctors G. Fine, M. S. Zafar, and R. C. Mellinger of Henry Ford Hospital, Detroit, Mich.

Patient 2. Details of this patient have been described elsewhere (17). Pancreatic islet tumor tissue $(1 \mathrm{~g})$ frozen at surgery $2 \mathrm{yr}$ previously was provided by Dr. R. Caplan of the Gunderson Clinic, LaCrosse, Wis. and Dr. R. V. Randall of the Mayo Clinic, Rochester, Minn.

Patient 3. The clinical course of this patient with gigantism and the demonstration of GH-releasing activity in his peripheral plasma have been reported in preliminary form (19). Lyophilized powder of the liver containing a metastatic carcinoid tumor at autopsy was provided by Dr. W. Daughaday of Washington University School of Medicine, St. Louis, Mo.

Tumor tissue was also obtained from eight other carcinoid tumors and lung carcinomas removed from patients with no clinical or hormonal evidence of $\mathrm{GH}$ hypersecretion. Tissue was obtained at the time of surgery or at autopsy and stored frozen for periods of up to $2 \mathrm{yr}$ before extraction.

\section{Extraction technique}

Tumor tissue and normal lung and pancreas, used as controls, were extracted with $2 \mathrm{~N}$ acetic acid using a Polytron homogenizer (Polytron Corp., Elkhart, Ind.), placed in a boiling water bath for $10 \mathrm{~min}$, and then centrifuged at $12,000 \mathrm{~g}$ for $20 \mathrm{~min}$ at $4^{\circ} \mathrm{C}$. The supernatant was lyophilized and stored at $-70^{\circ} \mathrm{C}$. Before subsequent studies, the residue was resuspended in $0.05 \mathrm{M}$ phosphosaline buffer, $\mathrm{pH} 7.5$ (PBS) or water at a concentration of $25-50 \mathrm{mg}$ tissue eq/ml and cleared by centrifugation at $12,000 \mathrm{~g}$ for $10 \mathrm{~min}$.

Porcine stalk median eminence (pSME) was extracted with $90 \%$ methanol as described (20). An aliquot of the pancreatic islet tumor was similarly extracted with $90 \%$ methanol.

\section{Bioassay systems}

Dispersed rat adenohypophyseal monolayer culture. A 4-d primary monolayer culture of enzymatically dispersed anterior pituitary cells from estrogen-primed male rats was used to detect pituitary hormone-releasing activity (21). Quadruplicate incubations of 4-h duration were performed in a total volume of $1 \mathrm{ml} \mathrm{Kreb's-Ringer} \mathrm{bicarbonate} \mathrm{buffer}$ containing $1 \%$ bovine serum albumin, $14 \mathrm{mM}$ glucose, and the test material, added in a volume of $50 \mu$ l or less. The concentrations of rat $\mathrm{GH}(\mathrm{rGH})$, prolactin, and thyrotropin released into the incubation medium were measured by radioimmunoassay as described $(22,23)$. Results are expressed as the mean $\pm \mathrm{SE}$. Student's $t$ test and analysis of variance were used to compare the significance of the differences.

Perifused rat anterior pituitary. Quartered anterior pituitaries from two or three 180-200 g male Holtzman rats were preincubated for $3 \mathrm{~h}$ in the presence of $\left[{ }^{3} \mathrm{H}\right] l$ leucine to provide a uniformly labeled pool of ${ }^{3} \mathrm{H}-\mathrm{rGH}$ as described (24). Explants were then transferred to a $0.3-\mathrm{ml}$ chamber and perifused with nonradioactive medium at $1 \mathrm{ml} / 5 \mathrm{~min}$ with fractions collected every $5 \mathrm{~min} .{ }^{3} \mathrm{H}$-rGH release was assessed using excess specific monkey anti-rGH serum or normal monkey serum and coprecipitating with goat anti-monkey immunoglobulin (Ig)G serum. Under these conditions, ${ }^{3} \mathrm{H}$ rGH release, expressed as a percentage of pituitary content per minute, is stable for at least $20 \mathrm{~h}$.

\section{Chromatography}

Gel filtration of the extract was performed on Sephadex G-10, G-25f, and G-75 (Pharmacia Fine Chemicals, Inc., Piscataway, N. J.) equilibrated and eluted with $1 \mathrm{~N}$ acetic acid. The column sizes and flow rates are indicated in the Results. Fractions of 2-4 ml were collected, lyophilized, and resuspended in PBS before bioassay. Measurements of protein concentration were made using absorbance at $280 \mathrm{~nm}$, the method of Lowry et al. (25) or by fluorescamine (26), which had been standardized with the Lowry method using the crude extract of the tumor as reference.

Ion-exchange chromatography was performed on DEAEcellulose or carboxymethylcellulose columns. $1 \mathrm{~g}$ of DEAEcellulose (DE-52, preswollen, microgranular, Whatman, Inc.,

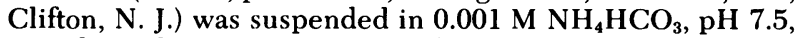
$\mathrm{pH}$ adjusted with $100 \% \mathrm{CO}_{2}$, and the slurry packed into a 1 $\times 2.5-\mathrm{cm}$ column. After thorough equilibration with $0.01 \mathrm{M}$ $\mathrm{NH}_{4} \mathrm{HCO}_{3}$ to a constant $\mathrm{pH}, 0.1 \mathrm{ml}$ of pancreatic tumor extract (200 $\mu \mathrm{g}$ protein) was applied and the column was eluted with four column volumes of buffer at a flow rate of $25 \mathrm{ml} / \mathrm{h}$. Further elution was carried out with three stepwise 10-fold increments of buffer concentration at a constant $\mathrm{pH}$. Each eluate was lyophilized, redissolved in $\mathrm{H}_{2} \mathrm{O}$ and dried in vacuo over $\mathrm{H}_{3} \mathrm{PO}_{4}$ crystals to remove residual $\mathrm{NH}_{4}{ }^{+}$ions. The final residue was reconstituted in $\mathrm{H}_{2} \mathrm{O}$ to the original $0.1 \mathrm{ml}$ vol and aliquots tested for GH-releasing activity in the same bioassay as the unchromatographed extract. Chromatography on CM-cellulose (CM-52, preswollen, microgranular, Whatman, Inc.) was carried out as described for DEAE, except that $0.001 \mathrm{M}$ ammonium acetate buffer, pH 6.4 was used initially and $\mathrm{NH}_{4}{ }^{+}$was employed as the counterion for pH adjustment.

Reversed-phase high pressure liquid chromatography (HPLC) of a crude extract of the pancreatic islet tumor was performed according to the method of Rivier (27) on a $\boldsymbol{\mu} \mathrm{CN}$ (cyanopropyl) column (Waters Associates, Inc., Milford, Mass.) equilibrated with $0.25 \mathrm{M}$ triethyl ammonium formate, $\mathrm{pH} 3.5,90 \%$; acetonitrile, $10 \%$. The lyophilized extract was dissolved in the same solvent, cleared by centrifugation, and injected onto the column through a Glenco model SV-7 sample injector valve (Glenco Scientific, Inc., Houston, Tex.). A Glenco model HPLPS-1 pumping system was used for elution with a linear gradient of $10-50 \%$ acetonitrile in a total 
volume of $100 \mathrm{ml}$, at a flow rate of $2 \mathrm{ml} / \mathrm{min}$. 2-ml fractions were collected, lyophilized, and reconstituted in PBS for bioassay and protein determination.

Estimates of recovery of GH-releasing activity from the different chromatographic procedures were made to assess their value for subsequent purification studies. The removal of inhibitor(s), however, renders these estimates quantitatively imprecise.

\section{Enzymatic hydrolysis}

The effect of human plasma and of various enzymes on the GH-releasing activity of the tumor extracts was studied by exposing them to plasma or to individual enzymes at $37^{\circ} \mathrm{C}$ for $30-60 \mathrm{~min}$ in the concentrations listed in the Results. Lyophilized tumor extracts and enzymes were dissolved in PBS. All solutions were placed in a boiling water bath for $10 \mathrm{~min}$ to destroy enzyme activity before bioassay. The following enzymes were used: pronase-CB (Streptomyces griseus, Calbiochem-Behring Corp., American Hoechst Corp., San Diego, Calif.), trypsin (bovine pancreas, Worthington Biochemical Corp., Freehold, N. J.), chymotrypsin (bovine pancreas, Worthington Biochemical Corp.), carboxypeptidase A-DFP (bovine pancreas, Type I, Sigma Chemical Co., St. Louis, Mo.), carboxypeptidase B-DFP (hog pancreas, Sigma Chemical Co.), leucine-aminopeptidase (hog kidney microsomes, Sigma Chemical Co.), and pyroglutamateaminopeptidase (calf liver, Boehringer Mannheim Biochemicals, Indianapolis, Ind.).

\section{Radioimmunoassay of somatostatin}

Somatostatin radioimmunoassay was performed by the method of Kronheim et al. (28) with minor modifications, using rabbit anti-somatostatin-hemocyanin serum (final dilution 1:75,000), ${ }^{125} \mathrm{I}_{\text {-tyr }}{ }^{1}$-somatostatin prepared by the lactoperoxidase-glucose oxidase method (29) and purified by ionexchange chromatography (CM-52), synthetic somatostatin standard, and second antibody precipitation in the presence of normal rabbit serum. $0.01 \mathrm{M}$ phosphate- $0.15 \mathrm{M}$ saline buffer, pH 7.8, to which $0.05 \mathrm{M}$ disodium EDTA and $0.5 \%$ crystalline bovine serum albumin had been added, was used for all dilutions. The assay has a sensitivity of $1.5 \mathrm{pg}$ somatostatin/tube and 15-25 pg peptide causes $50 \%$ tracer displacement. The antiserum has been previously characterized and is directed against positions 6-9 of the tetradecapeptide.

\section{Other chemicals and their sources}

Somatostatin (Ayerst Laboratories, New York), prostaglandin $\mathrm{E}_{1}$ (Upjohn Co., Kalamazoo, Mich.), insulin, glucagon, and pancreatic polypeptide (Eli Lilly \& Co., Indianapolis, Ind.), calcitonin (Armour Pharmaceutical Co., Scottsdale, Ariz.), cholecystokinin-octapeptide (E. R. Squibb \& Sons, Princeton, N. J.), substance P (Dr. J. Rivier, Salk Inst.), gastric inhibitory peptide (National Institutes of Health), and secretin and vasoactive intestinal peptide (Professor V. Mutt, Karolinska Inst.) were provided as gifts. 5-hydroxytryptophan, norepinephrine, histamine (Sigma Chemical Co.), bradykinin (Peninsula Laboratories, Inc., San Carlos, Calif.), dopamine (Calbiochem-Boehring Corp.), and serotonin (Mann Chemical Corp., Louisville, Ky.) were purchased from commercial sources.

\section{RESULTS}

Comparison of GH-releasing activity in the various tumors. GH-releasing activity, measured in the pituitary monolayer culture system, was present in tumors from the three patients with GH hypersecretion and in tumors from two other patients with no clinical and/or biochemical evidence of GH hypersecretion (Table I). The highest level of activity, as measured by both the maximal stimulation above control and the quantity of extract required for the least detectable dose, was present in the pancreatic islet tumor (patient 2). Slightly less, though moderate amounts of activity were present in the two other carcinoids associated with GHhypersecretion (patients 1 and 3). Smaller, but significant amounts of GH-releasing activity were pres-

TABLE I

Comparison of GH-releasing Activity in Tumors*

\begin{tabular}{|c|c|c|c|c|}
\hline \multirow[b]{3}{*}{ Tumor } & \multirow[b]{3}{*}{ Plasma GH } & \multicolumn{3}{|c|}{ Tumor GH-releasing activity } \\
\hline & & \multicolumn{2}{|c|}{$\begin{array}{l}\text { Least detectable } \\
\text { dose }\end{array}$} & \multirow{2}{*}{$\begin{array}{l}\text { Maximal stimulation } \\
\text { above control }\end{array}$} \\
\hline & & Tissue & Protein & \\
\hline & $n g / m l$ & $m g$ & $\mu g$ & $\%$ \\
\hline Bronchial carcinoid (patient No. 1) & $31 \ddagger$ & 0.25 & 3 & 82 \\
\hline Pancreatic islet tumor (patient No. 2) & $24 \S$ & 0.025 & 0.75 & $141 \pm 16(n=11)$ \\
\hline Abdominal carcinoid, metastatic to liver (patient No. 3) & $178^{\|}$ & 0.33 & 8.5 & 119 \\
\hline Bronchial carcinoid & 1.0 & 2.5 & 33 & 55 \\
\hline Small cell carcinoma of lung & 1.2 & 5.0 & 82 & 179 \\
\hline
\end{tabular}

* Activity was determined in the dispersed pituitary monolayer culture system.

\$ Reference 18; value obtained 6 yr after "hypophysectomy" and stalk section.

\$ Reference 17.

"Reference 19; immunoreactive GH was identified in tumor tissue (presented by Dr. W. Daughaday in discussion at the Annual Meeting, Association of American Physicians, Washington, D. C., 6 May, 1979).

I $P<0.05$ vs. control; $P$ values of all other responses were $<0.01$ vs. control. 
ent in two tumors from patients with normal $\mathrm{GH}$ levels (patients 4 and 5), whereas no GH-releasing activity was present in six other tumors (three bronchial carcinoid, one pancreatic islet tumor, and two lung carcinomas). Similarly extracted normal human lung (two patients) and pancreas (one patient) exhibited no GH-releasing activity.

Concomitant measurement of prolactin and thyrotropin in the incubation medium indicated that the tumor extracts from patients 1,2 , and 3 did not stimulate the release of either hormone.

Because of the differences in activity of the various tumors and the limited availability of tissue, only a few of the studies were performed using the bronchial carcinoid tumor extract (patient 1). The remainder used the pancreatic islet tumor extract.

GH-releasing activity was not detected in a methanol extract of the pancreatic islet tumor. The activity was, however, subsequently extracted from the methanol insoluble residue with $2 \mathrm{~N}$ acetic acid.

Effect of somatostatin on GH-releasing activity. The effect of somatostatin on the GH-releasing activity of the bronchial carcinoid extract is shown in Table II. This concentration of somatostatin $(1 \mathrm{nM})$ has been previously shown to completely suppress the stimulatory effect of dibutyryl-cyclicAMP on GH release by pituitary monolayer cultures (30). Somatostatin slightly inhibited the basal release of $\mathrm{GH}$ and completely blocked the stimulatory effect of the bronchial carcinoid extract.

Effect of tumor extracts on GH release by perifused anterior pituitaries. The stimulatory effect of the bronchial carcinoid extract was assessed in a pituitary perifusion system and compared with that of pSME and of normal human lung. The GH response to a 15min pulse of the carcinoid extract was immediate and reached a peak of greater than twice basal values (Fig. 1). The response persisted for a brief period after termination of the pulse, after which $\mathrm{GH}$ release re-

\section{TABLE II}

Effect of Somatostatin on the GH-releasing Activity of Bronchial Carcinoid Tumor Extract

\begin{tabular}{lc}
\hline & \multicolumn{1}{c}{$\mathrm{rGH}^{*}$} \\
\hline & $n g / m l$ \\
& $362 \pm 23$ \\
Control & $306 \pm 15 \ddagger$ \\
Bromatostatin, $1 \mathrm{nM}$ & $610 \pm 37 \S$ \\
Bronchial carcinoid, $7.5 \mu \mathrm{g}$ protein/ml carcinoid + somatostatin & $263 \pm 37 \ddagger^{\prime \prime}$ \\
\hline *GH release was measured during a 4-h period in pituitary \\
monolayer cultures. Shown are the mean $\pm \mathrm{SE}$. \\
$\ddagger P<0.05$ vs. control (one tailed $t$ test). \\
$\$ P<0.01$ vs. control. \\
$" P<0.0 \mathrm{i}$ vs. bronchial carcinoid.
\end{tabular}

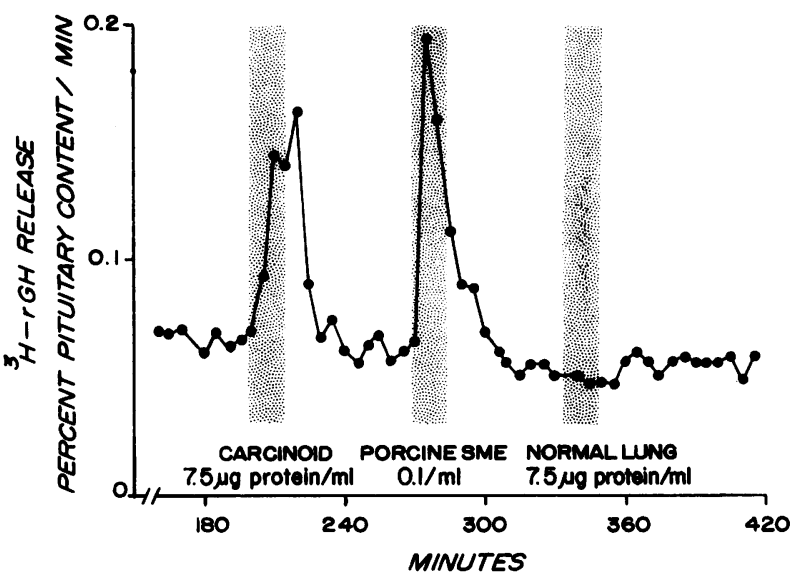

FIGURE 1 Effect of extracts of bronchial carcinoid tumor, pSME, and normal human lung on the release of previously labeled ${ }^{3} \mathrm{H}-\mathrm{rGH}$ from perifused rat anterior pituitaries, isolated by specific immunoprecipitation. Pulses of each test substance, indicated in the shaded area, were of 15-min duration. The pituitaries were perifused with buffer for $2 \mathrm{~h}$ to permit a stable base-line release rate to be established before introduction of the pulses.

turned to base-line levels. The stimulatory response was comparable to that observed to pSME with the exception that the GH secretory response to pSME was of shorter duration, decreasing during the last 10 min of the pulse, as has been reported (31). An extract of normal lung did not stimulate GH release.

An extract of the pancreatic islet tumor elicited a stimulatory response comparable to that of bronchial carcinoid tumor (data not shown). An extract of normal pancreas slightly inhibited $\mathrm{GH}$ release by perifused rat pituitaries. This effect could be attributed to its somatostatin content.

Dose-related effects of tumor extracts on GH release. The pancreatic tumor extract stimulated GH release by cultured pituitary cells in the range of $0.9-9.0 \mu \mathrm{g}$ protein, shown in Fig. 2. At concentrations above this level, no further increase was seen. In other experiments, a significant stimulation of $\mathrm{GH}$ release has been observed with as little as $0.75 \mu \mathrm{g}$ protein. A doseresponsive increase in $\mathrm{GH}$ release has been observed with an extract of the bronchial carcinoid tumor (18).

Somatostatin-like immunoreactivity content of tumor tissue. The somatostatin-like immunoreactivity (SRIF-LI) of the tumors was measured in the crude tissue extract. A comparison of the values for each tumor is shown in Table III. Also shown is the quantity of tumor extract required to demonstrate somatostatin bioactivity based on a minimal effective dose of 33 pM (30). The results, when compared with the data in Table I indicate that the minimal quantity of tissue extract required to demonstrate GH-releasing activity from the three most potent tumors was 8-30 times less than that required to show the inhibitory 


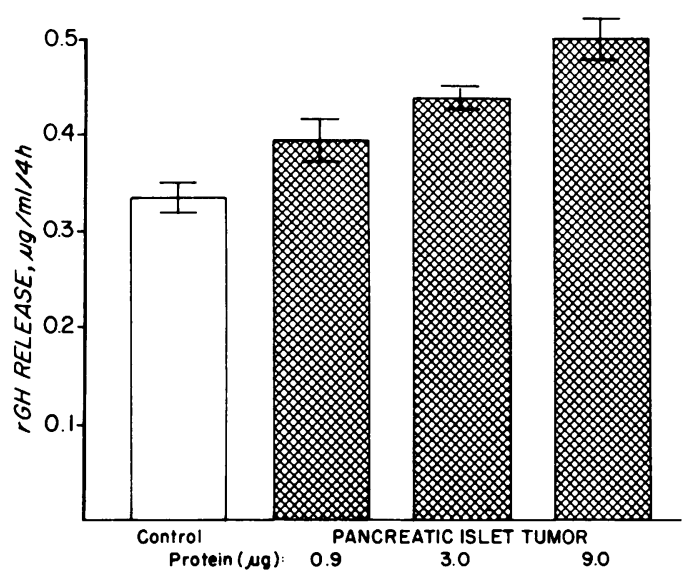

FIgURE 2 Effect of increasing concentrations of a crude extract of the pancreatic islet tumor on the release of $\mathrm{rGH}$ by dispersed pituitary monolayer cultures. Shown are the mean $\pm S E$ of four replicate cultures incubated for a 4 -h period. $\mathrm{P}=0.05$ for lowest dose and $<0.01$ for other doses vs. control.

effects of somatostatin. In the two less potent tumors, however, the SRIF-LI concentration was probably sufficient to exert an inhibitory effect even at the lowest dose tested. In each of the extracts, demonstrable effects of somatostatin would be expected with increasing doses.

Sephadex gel filtration of tumor GH-releasing activity. The molecular size of the GH-releasing activity was initially estimated by Amicon membrane filtration (American Instrument Co., Silver Spring, Md.). All of the activity was retained by a UM-2 membrane (molecular exclusion size $\sim 2,000$ daltons) and approximately one-half was retained by a UM-10 membrane $(\sim 10,000$ dalton exclusion size $)$. The elution pattern of the pancreatic islet tumor extract gel filtered on Sephadex G-10 revealed the GH-releasing

TABLE III

SRIF-LI Content of Tumors with GH-releasing Activity

\begin{tabular}{lcc}
\hline \multicolumn{1}{c}{ Tumor } & SRIF-LI & $\begin{array}{c}\text { Tissue required } \\
\text { for detection } \\
\text { of bioactivity* }\end{array}$ \\
\hline & $n g / g$ & $m g$ \\
Bronchial carcinoid (patient No. 1) & 6.8 & 7.8 \\
Pancreatic islet tumor (patient No. 2) & 226 & 0.24 \\
Abdominal carcinoid metastatic to & & \\
$\quad$ liver (patient No. 3) & 20 & 2.7 \\
Bronchial carcinoid & 14.4 & 3.7 \\
Small cell carcinoma of lung & 14.0 & 3.8 \\
Normal pancreas & 880 & 0.06 \\
Normal lung & 2.4 & 22.1 \\
\hline
\end{tabular}

* A somatostatin concentration of at least $33 \mathrm{pM}$ is required for detection of inhibitory effects on stimulated GH secretion in the cultured pituitary cell system (30). activity to be present in the void volume of the column along with SRIF-LI and the majority of the protein.

The pancreatic islet tumor extract was next gel filtered on Sephadex G-25f (Fig. 3). The GH-releasing activity again eluted entirely in the void volume of the column. SRIF-LI eluted in a biphasic manner with a small void volume peak and a large retarded peak in a position identical to that of synthetic somatostatin. A small but significant inhibition of $\mathrm{GH}$ release was present in the region of the major somatostatin peak.

The Sephadex G-75 elution pattern of the pancreatic islet tumor is shown in Fig. 4. The peak of the $\mathrm{GH}$ releasing activity eluted with a $K_{d}$ of 0.67 . In four separate Sephadex G-75 filtrations of the pancreatic islet tumor extract, the $K_{\mathrm{d}}$ range of the peak of $\mathrm{GH}$ releasing activity was from 0.58 to 0.67 indicating an apparent molecular size slightly larger than that of insulin. No GH-releasing activity was present in the void volume. The overall recovery of $\mathrm{GH}$-releasing activity from Sephadex G-75 gel filtration appeared to be $60-70 \%$. Sephadex G-75 gel filtration of an extract of the carcinoid tumor from patient No. 3 revealed a similar pattern, whereas that of the bronchial carcinoid resulted in two peaks of GH-releasing activity: one which eluted in the void volume and the other which coincided with the major peak of the pancreatic islet tumor bioactivity.

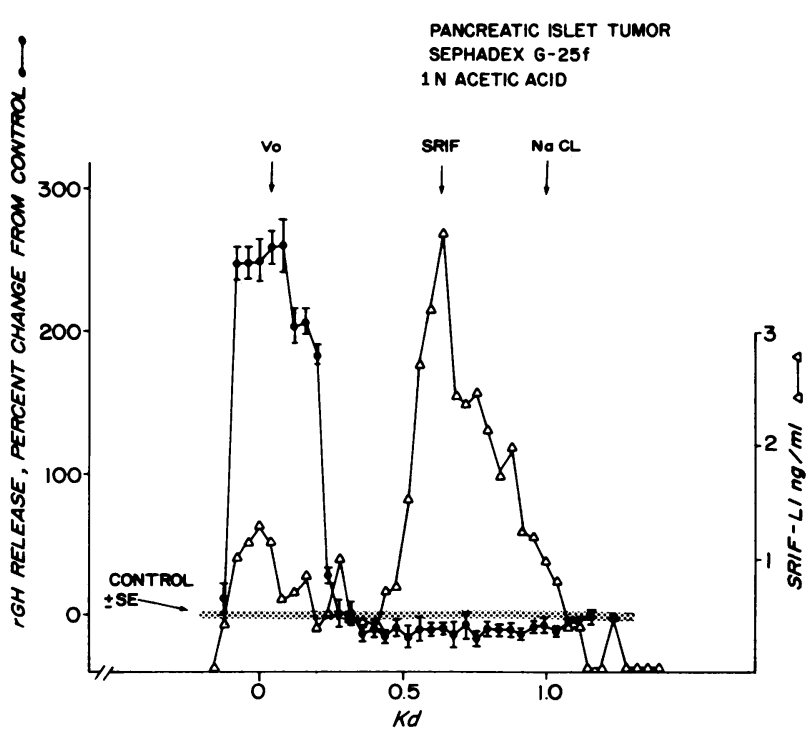

Figure 3 Sephadex G-25f gel filtration of a crude extract of the pancreatic islet tumor. Column size was $2.2 \times 90 \mathrm{~cm}$ and $4-\mathrm{ml}$ fractions were collected at a flow rate of $30 \mathrm{ml} / \mathrm{h}$. $\mathrm{GH}$-releasing activity, in solid circles, is shown as the mean $\pm \mathrm{SE}$ of rat $\mathrm{GH}(\mathrm{rGH})$ released by four replicate pituitary monolayer cultures expressed in terms of basal $\mathrm{rGH}$ release, shown in the shaded area. Maximal stimulatory response to the crude extract was $+106 \pm 9 \%$. SRIF-LI is indicated in the open triangles. 


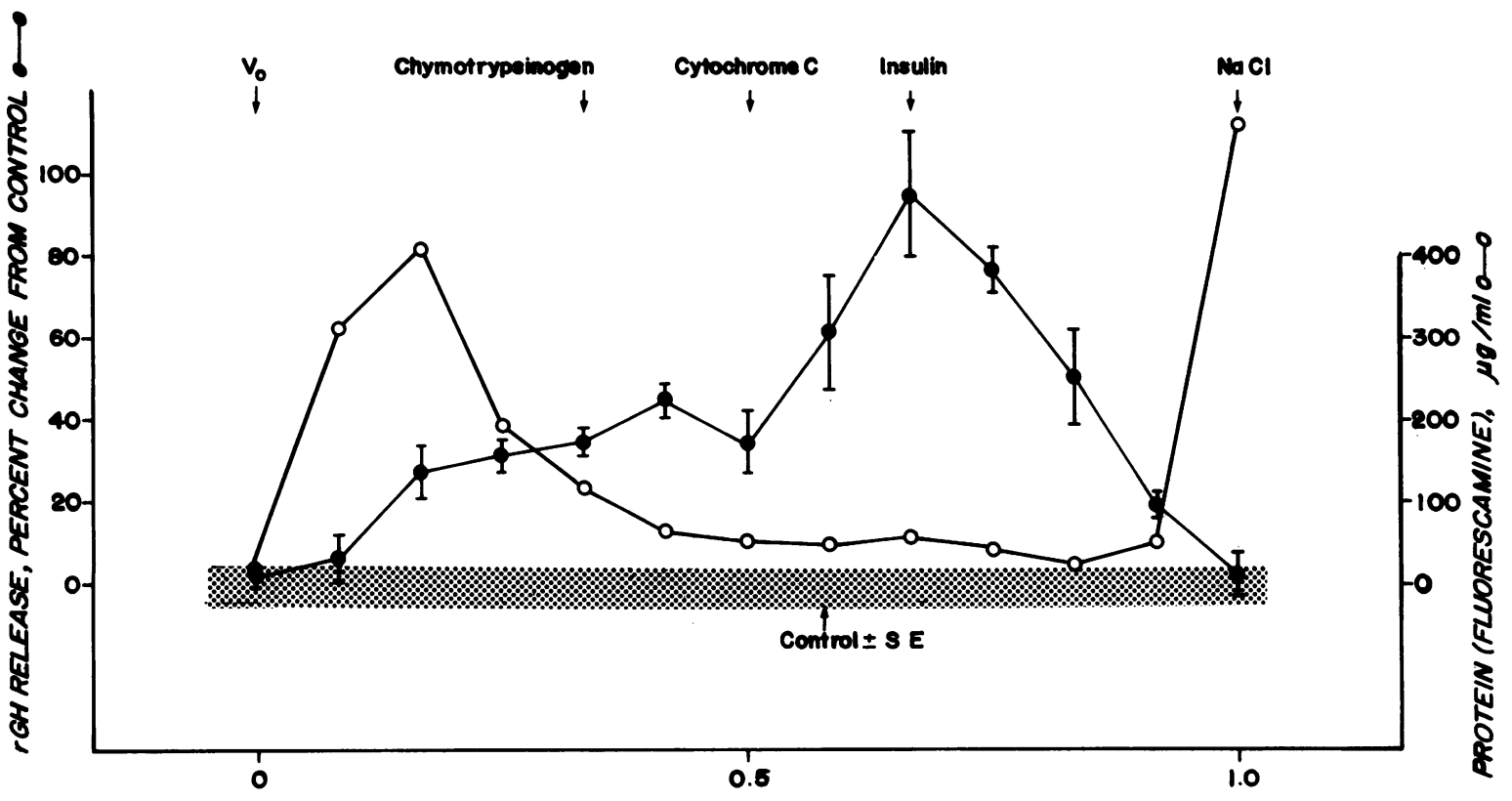

\begin{abstract}
Kd
Figure 4 Sephadex G-75 gel filtration of a crude extract of the pancreatic islet tumor extract. Column size was $0.9 \times 55 \mathrm{~cm}$ and $2-\mathrm{ml}$ fractions were collected at a flow rate of $3 \mathrm{ml} / \mathrm{h}$. $\mathrm{GH}$ releasing activity, in solid circles, is expressed as in Fig. 3. Maximal stimulatory response to the crude extract was $+135 \pm 13 \%$. Protein concentration, in open circles, was measured using fluorescamine.
\end{abstract}

Ion-exchange chromatography of tumor GH-releasing activity. The pancreatic islet tumor extract was subjected to ion exchange chromatography using anion- and cation-exchange resins. The majority of the GH-releasing activity was not retained by CM-cellulose under slightly acidic conditions and low ionic strength (Fig. 5), whereas a portion of the bioactivity appeared to have been irreversibly retained by the resin. GH-releasing activity was completely bound to DEAE-cellulose at $\mathrm{pH} 7.5$ and low ionic strength and could be eluted by increasing the ionic strength to $0.1 \mathrm{M}$ or greater. Although nearly all of the bioactivity appeared to be recovered from DEAE-cellulose on a small scale, attempts to reproduce these conditions on a preparative scale were unsuccessful.

HPLC of tumor GH-releasing activity. The crude pancreatic islet tumor extract was further purified by HPLC using an acetonitrile gradient for elution (Fig. 6). At least 12 different peptide/protein peaks were identified in the extract. GH-releasing activity, determined initially in pools of five fractions and subsequently in individual fractions, was present in only one, which was eluted at an acetonitrile concentration of $\sim 26 \%$ and was contained within one of the minor peptide peaks.
SRIF-LI was eluted at a lower acetonitrile concentration $(\sim 23 \%)$ and was unassociated with a detectable peptide peak.

Dose-response effects of partially purified GHreleasing activity. A dose-response curve using the Sephadex G-25 purified peak of pancreatic islet tumor GH-releasing activity is shown in Fig. 7. The maximum GH release response achieved, five times basal levels, was more than three times that observed with the crude pancreatic islet tumor extract in the same bioassay.

Enzymatic studies. Crude extracts of the bronchial carcinoid and pancreatic islet tumor were incubated with pronase, a broad spectrum protease. The GHreleasing activity in both tumor extracts was completely destroyed by pronase treatment (Table IV).

The effect of plasma enzymes on the crude pancreatic islet tumor extract is shown in Fig. 8. The GH-releasing activity of the extract was partially inhibited by incubation with plasma for $60 \mathrm{~min}$ at $37^{\circ} \mathrm{C}$.

Crude or partially purified pancreatic islet tumor GHreleasing activity was subjected to treatment with a series of enzymes, the results of which are shown in Table V. Exposure of the crude extract to either trypsin or chymotrypsin resulted in a complete loss of releasing 


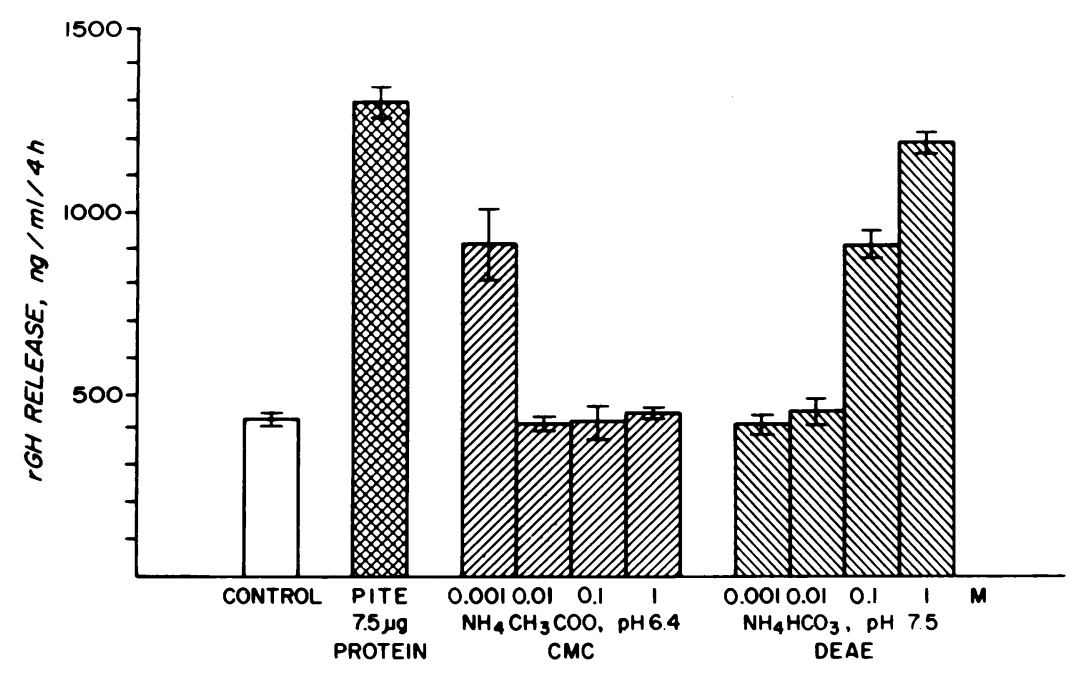

FIGURE 5 Ion-exchange chromatography of an extract of the pancreatic islet tumor (PITE). Shown are the mean $\pm \mathrm{SE}$ of the $\mathrm{GH}$-releasing activity eluted from the exchange resins as determined in pituitary monolayer cultures. The extract was applied to the CM-cellulose column in $0.001 \mathrm{M}$ ammonium acetate buffer, $\mathrm{pH}$ 6.4, and eluted with increasing salt concentration. An identical quantity of extract was applied to the DEAE cellulose column in $0.001 \mathrm{M}$ ammonium bicarbonate buffer, pH 7.5 and eluted in a similar manner.

activity. In parallel experiments, exposure of synthetic somatostatin to either enzyme destroyed its GH release-inhibitory activity (data not shown).

Further studies were performed with GH-releasing activity partially purified by Sephadex G-75. Exposure to trypsin or chymotrypsin again destroyed all biologic activity. GH-releasing activity was resistant to carboxypeptidase $\mathrm{A}$ and $\mathrm{B}$, leucine-aminopeptidase, and pyroglutamate-aminopeptidase. Inactivated enzymes used in control incubations did not inhibit the response of the cultured cells to provocative stimuli.

Effects of other agents on GH release by pituitary monolayer cultures. Several potential secretory products of carcinoid or pancreatic islet tumors were evaluated for their GH-releasing activity in the pituitary monolayer culture. Serotonin, norepinephrine, dopamine, and histamine at concentrations of $0.1-10 \mu \mathrm{M}$ were all inactive as was 5-hydroxytryptophan $(1-100 \mu \mathrm{M})$. Cholecystokinin-octapeptide, secretin, substance $P$, insulin, vasoactive intestinal peptide, gastric inhibitory peptide, pancreatic polypeptide, glucagon, and calcitonin at concentrations of $0.01-1 \mu \mathrm{M}$ were also nonstimulatory. Bradykinin at concentrations of $10 \mu \mathrm{M}$ and greater stimulated both GH and PRL release. Prostaglandin $E_{1}$ at $10 \mu \mathrm{M}$ stimulated $\mathrm{GH}$ release but its activity would not be expected to be destroyed by proteolytic enzymes.

\section{DISCUSSION}

Our results have demonstrated the presence of $\mathrm{GH}$ releasing activity in five different tumors, three of which were associated with GH hypersecretion and acromegaly. The releasing activity in the tumors varied considerably, which may have been caused, in part, by the different duration and conditions of storage of the tumors. The relative stability of GH-releasing activity appears considerable, however, in view of the persistence of activity for up to $7 \mathrm{yr}$. Furthermore, the GHreleasing activity of the tumor tissue tended to correlate with its biologic expression in individual patients, the three tumors with the highest levels occurring in those patients with GH hypersecretion. The results, therefore, suggest that a relationship exists between the level of GH-releasing activity in the tumor and its secretion rate.

All of the tumors contained measurable SRIF-LI and levels in one, the pancreatic islet tumor, were much greater than in the others. Since somatostatin is normally found in the islet D cells, this observation is not surprising. On the basis of the clinical expression of the tumors or the lack thereof, it appears that the production of somatostatin by the tumors may not have contributed greatly to their net biologic effects on GH secretion.

GH-releasing activity was demonstrated in two different in vitro systems: dispersed pituitary monolayer cultures and perifused hemipituitaries. The latter is the closest available simulation of an in vivo model, which was not used because of the limited availability of GHreleasing activity. The kinetics of tumor extract-stimulated GH release during perifusion were similar to those of pSME in terms of the rapidity of the response. The persistence of the stimulatory response throughout 


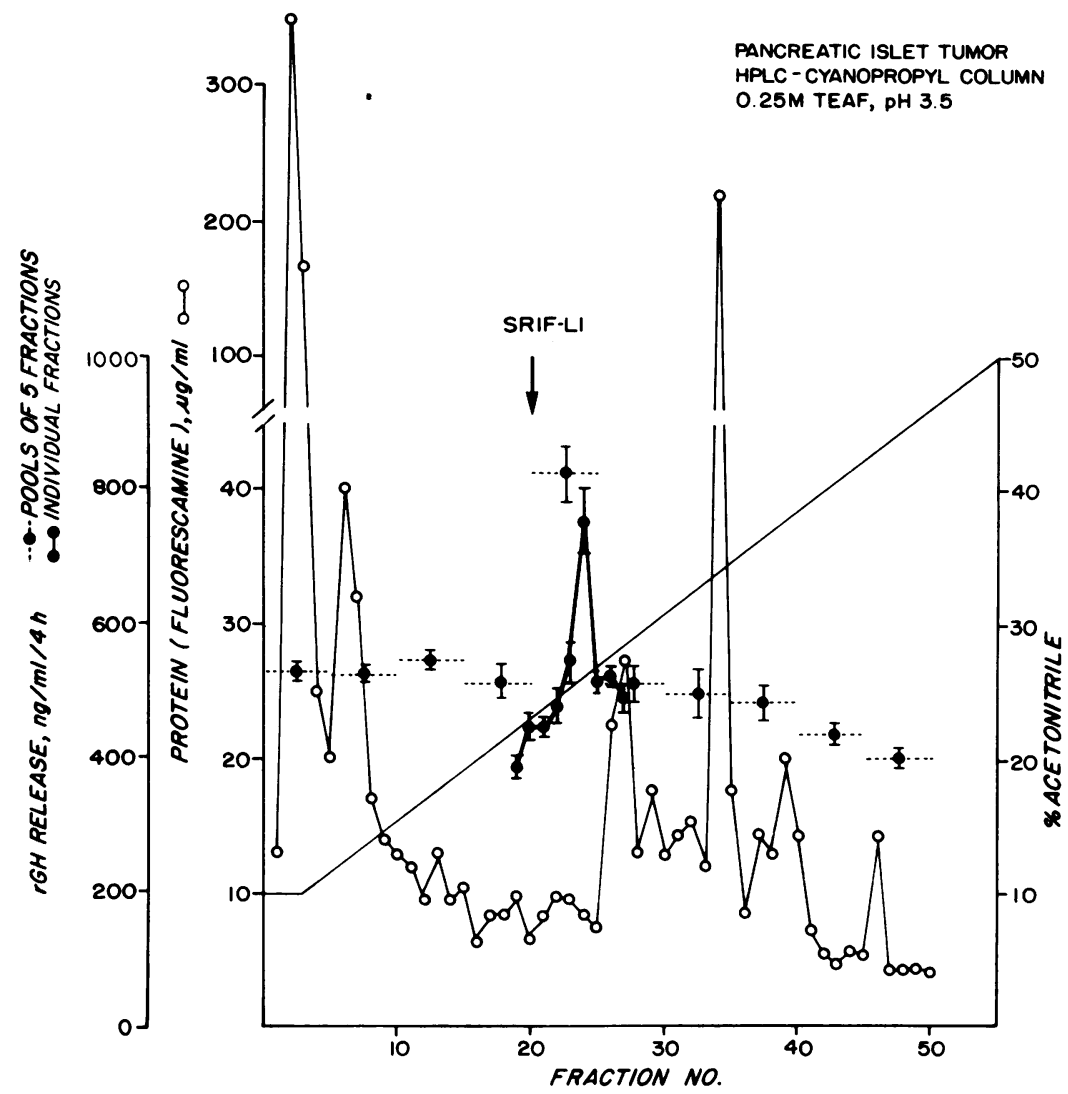

FIgURE 6 Purification of pancreatic islet tumor GH-releasing activity on HPLC. The crude extract of the pancreatic islet tumor was applied to a cyanopropyl column and eluted with $0.25 \mathrm{M}$ triethyl ammonium formate (TEAF), pH 3.5 using a 10-50\% acetonitrile gradient. Fractions of $2-\mathrm{ml} \mathrm{vol} \mathrm{were} \mathrm{collected} \mathrm{at} \mathrm{a} \mathrm{flow} \mathrm{rate} \mathrm{of} 2 \mathrm{ml} / \mathrm{min}$. GH-releasing activity, shown in closed circles, represents the mean $\pm S E$ of four replicate cultures. Pools of five fractions each, indicated by the horizontal broken lines, were initially assayed for biologic activity and, in a second assay, individual fractions within and extending slightly beyond the active pool were retested. The release of $\mathrm{GH}$ by control cultures was $519 \pm 16 \mathrm{ng} / \mathrm{ml}$ in the assay of pooled fractions and $489 \pm 10 \mathrm{ng} / \mathrm{ml}$ in the assay of individual fractions. Protein concentration, shown in open circles, was determined by the fluorescamine method.

and even beyond the pulse of the bronchial carcinoid extract contrasted with the short-duration response to pSME, which has been attributed to concomitant high somatostatin levels (31). The concentration of somatostatin in the bronchial carcinoid extract used for perifusion $(2.5 \mathrm{pM})$ was considerably lower than the least detectable dose required $(250 \mathrm{pM})$ in the perifusion system (32).

The stimulatory effects of the tumor GH-releasing activity were inhibited, as expected, by synthetic somatostatin. Similar results on the GH-releasing activity of pSME have been demonstrated in vivo (20) and in perifusion (31) and suggest that the release of GH was not simply the result of a depolarizing effect or of toxicity (33). The inhibitory effect of somatostatin also provides an explanation for the shallow doseresponse curve of the crude pancreatic islet tumor extract and the limited maximal stimulatory level of each of the crude extracts. It is, however, possible that inhibitory effects in the crude extracts were due to factors in addition to somatostatin.

Gel filtration of the pancreatic tumor and/or bronchial carcinoid tumor extract on Sephadex G-10 and G-25 under acidic conditions revealed all of the GH-releasing activity to be in the void volume. These results were surprising because they indicated a molecular size considerably greater than those of the identified and characterized hypothalamic releasing factors. The elution position of the major peak of activity from both tumors on Sephadex G-75 suggested a molecular size slightly larger than 6,000 daltons. In addition, heterogeneity was present in both tumors with releasing activity from the pancreatic islet tumor present in the $15,000-35,000$ dalton range and that from the bronchial carcinoid in the void volume. Even the smallest molecular size observed indicates the 


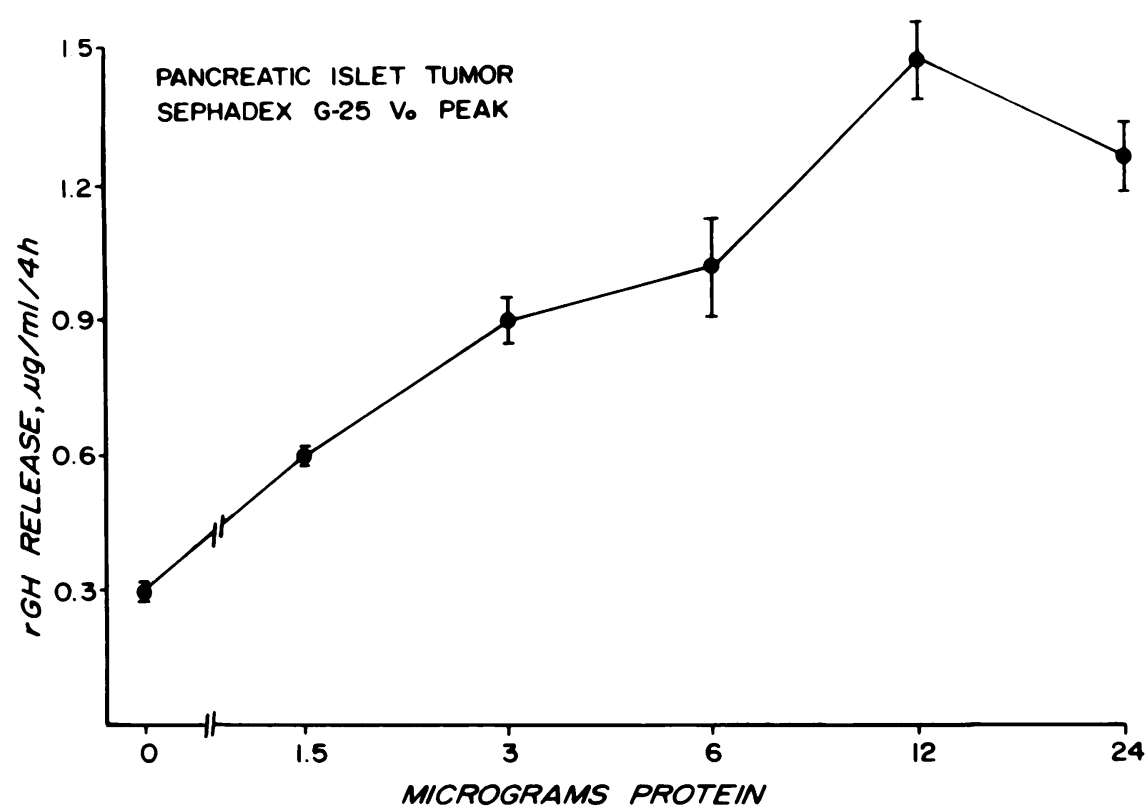

FIGURE 7 Dose-response curve of partially purified pancreatic islet tumor GH-releasing activity. The void volume peak of releasing activity from the Sephadex G-25 column (Fig. 3) was used. Shown are the mean $\pm S E$ of $G H$ release by four replicate cultures. Maximal stimulatory effect of five times basal values occurred with $12 \mu \mathrm{g}$ protein $/ \mathrm{ml}$. GH release in the presence of a maximally stimulatory dose of the crude extract was $643 \pm 60 \mathrm{ng} / \mathrm{ml}$.

tumor GH-releasing activity to be different from GHRF present in hypothalamic extracts as reported by others $(34,35)$ and confirmed by ourselves (unpublished observations). Additional evidence for this difference is provided by our inability to extract GH-releasing activity from the pancreatic islet tumor with $90 \%$

TABLE IV

Effect of Pronase Treatment on GH-releasing Activity of Tumor Extracts

\begin{tabular}{lc}
\hline \multicolumn{1}{c}{ Experiment } & $\mathrm{rGH}^{*}$ \\
\hline & $n g / \mathrm{ml}$ \\
I $\quad$ Control & $228 \pm 8$ \\
$\quad$ Pronase (inactivated) & $255 \pm 14$ \\
II Control $\quad 873 \pm 61$ \\
$\quad$ Bronchial carcinoid tumor extract, 7.5 & \\
$\quad \mu g$ protein/ml & $1,362 \pm 70 \ddagger$ \\
$\quad$ Bronchial carcinoid + pronase & $810 \pm 23$ \\
III Control & $764 \pm 19$ \\
$\quad$ Pancreatic islet tumor extract, $16 \mu \mathrm{g}$ & $1,473 \pm 166 \ddagger$ \\
$\quad$ protein/ml & $782 \pm 28$ \\
$\quad$ Pancreatic islet tumor + pronase &
\end{tabular}

* Crude extracts of the bronchial carcinoid and pancreatic islet tumors were incubated at $37^{\circ} \mathrm{C}$ for $30 \mathrm{~min}$ with or without pronase, $500 \mu \mathrm{g} / \mathrm{ml}$. The mixtures then boiled for $10 \mathrm{~min}$, appropriately diluted, and added to pituitary monolayer cultures.

† Significantly greater than control, $P<0.01$. methanol, whereas hypothalamic GHRF is readily extracted with this solvent (20). A possible explanation for this difference is the production of a precursor molecule by the tumor that exhibits biologic activity. Larger molecular sized forms of biologically active ACTH (36) and somatostatin (30) have also been demonstrated in ectopic tumors. The preliminary report that the GH-releasing activity in plasma from pa-

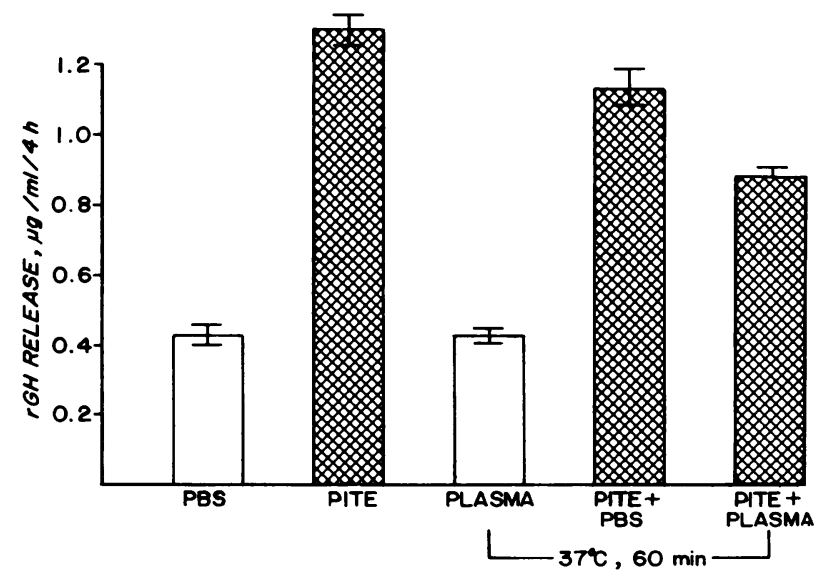

FIGURE 8 Effect of incubation with plasma on the GHreleasing activity of the pancreatic islet tumor extract (PITE). The extract was incubated with control PBS or normal human plasma for $60 \mathrm{~min}$ at $37^{\circ} \mathrm{C}$ and then tested for GH-releasing activity in pituitary monolayer cultures. Shown are the mean $\pm \mathrm{SE}$ of four replicate cultures. 
TABLE V

Effect of Enzyme Treatment on Crude and Partially Purified Pancreatic Islet Tumor GH-Releasing Activity

\begin{tabular}{|c|c|c|}
\hline \multirow[b]{2}{*}{ Treatment } & \multicolumn{2}{|c|}{$\mathrm{rGH}, n g / m l$} \\
\hline & Control & $\begin{array}{l}\text { GH-releasing } \\
\text { activity }\end{array}$ \\
\hline \multicolumn{3}{|l|}{$\begin{array}{c}\text { Crude pancreatic islet tumor } \\
\text { GH-releasing activity }\end{array}$} \\
\hline None & $304 \pm 9$ & $643 \pm 60^{*}$ \\
\hline Trypsin, $500 \mu \mathrm{g} / \mathrm{ml}$ & $245 \pm 23$ & $282 \pm 20$ \\
\hline Chymotrypsin, $500 \mu \mathrm{g} / \mathrm{ml}$ & $249 \pm 23$ & $304 \pm 7$ \\
\hline $\begin{array}{l}\text { Sephadex G-75 purified } \\
\text { GH-releasing activity }\end{array}$ & & \\
\hline None & $367 \pm 10$ & $922 \pm 49 *$ \\
\hline Trypsin, $50 \mu \mathrm{g} / \mathrm{ml}$ & $384 \pm 22$ & $394 \pm 8$ \\
\hline Chymotrypsin, $50 \mu \mathrm{g} / \mathrm{ml}$ & $360 \pm 37$ & $392 \pm 33$ \\
\hline Carboxypeptidase A, $50 \mu \mathrm{g} / \mathrm{ml}$ & $348 \pm 23$ & $892 \pm 69 *$ \\
\hline Carboxypeptidase B, $50 \mu \mathrm{g} / \mathrm{ml}$ & $339 \pm 18$ & $1,027 \pm 115^{*}$ \\
\hline $\begin{array}{l}\text { Leucine-aminopeptidase, } \\
50 \mu \mathrm{g} / \mathrm{ml}\end{array}$ & $290 \pm 21$ & $1,013 \pm 39^{*}$ \\
\hline $\begin{array}{l}\text { Pyroglutamate-aminopeptidase, } \\
50 \mu \mathrm{g} / \mathrm{ml}\end{array}$ & $400 \pm 20$ & $898 \pm 132 *$ \\
\hline
\end{tabular}

Partially purified GH-releasing activity was incubated at $37^{\circ} \mathrm{C}$ for 60 min with or without individual enzymes at the concentrations shown. Control incubations were performed with inactivated enzymes. The incubation mixtures were then placed in a boiling water bath for 5 min to inactivate the enzymes, diluted appropriately, and added to pituitary monolayer cultures.

* Significantly greater than control, $P<0.01$.

tient No. 3 is retarded on Sephadex G-25 (19) raises the possibility that the molecule present in the tumor tissue is cleaved prior to its release into the circulation. However, the structures of both hypothalamic GHRF and the GH-releasing activity from the tumors described in the present report are yet undetermined and the two substances could be structurally dissimilar.

Filtration through membranes of discrete pore size was consistent with the estimates of molecular size obtained from Sephadex gel filtration. All activity was of a size $>2,000$ daltons and a major portion was $<10,000$ daltons. The use of these membranes for purification was not pursued because of the relatively large losses encountered.

Ion-exchange chromatography provided additional information concerning the net charge of pancreatic tumor GH-releasing activity. At a neutral $\mathrm{pH}$ and low ionic strength, the molecule was negatively charged, as indicated by its adsorption onto DEAE cellulose.

Purification of GH-releasing activity resulted from two factors. First, the removal of inactive proteins led to an increase in specific activity. Second, the removal of an inhibitor, i.e., somatostatin, led to an increase in biologic activity without any discernible change in protein concentration. Thus, the "purity" of pancreatic islet tumor GH-releasing activity was not significantly increased by filtration through Sephadex G-25 as nearly all of the protein also eluted in the void volume. However, the biologic activity more than doubled as a consequence of removal of most of the somatostatin. Filtration through Sephadex G-75 led to a removal of both inactive protein and somatostatin, resulting in a purification of at least 20 times. An additional sixfold purification was achieved by a reversed-phase HPLC system which has previously been shown to be of value in separating peptides of a similar molecular size range (27).

Even partial purification of pancreatic islet tumor GH-releasing activity led to a marked increase in the sensitivity of the dose-response curve. The fivefold increase in maximal response was not only more than twice that generally observed with crude material but the extent of stimulation was also greater than we have observed in any other naturally occurring material. Using HPLC-purified material we have demonstrated stimulation with as little as $40 \mathrm{ng} / \mathrm{ml}$ of protein or (assuming a mol wt of 8,000$) 5 \mathrm{nM}$, which is of the same order of magnitude as observed with other releasing factors in this system (37).

Additional characterization of tumor GH-releasing activity was achieved through a series of enzyme studies. The peptide nature of GH-releasing activity was initially established on crude extracts using pronase, a broad spectrum protease. This was confirmed on partially purified pancreatic islet tumor GHreleasing activity using the endopeptidases chymotrypsin and trypsin, suggesting the presence of lysine and/or arginine and of aromatic residues at an active site of the molecule. The use of exopeptidases also provided important information. The inability of carboxypeptidases and aminopeptidases to destroy the biologic activity suggests the possibility that the $\mathrm{COOH}$ terminal and $\mathrm{NH}_{2}$-terminal residues are blocked and/or that neither terminus is required for releasing activity. A comparison of the responses to enzymatic treatment of the pancreatic islet tumor GH-releasing activity and those recently reported by Nair et al. (35) using a partially purified bovine hypothalamic GHRF reveals identical susceptibility to endopeptidase treatment. In contrast, the biologic activity of hypothalamic GHRF was completely destroyed by carboxypeptidase or pyroglutamate aminopeptidase. These differences, coupled with the fact that bovine hypothalamic GHRF was retarded on Sephadex G-25 indicating a smaller molecular size, suggest one of two possibilities: $(a)$ the two molecules are structurally dissimilar, or $(b)$ tumor GH-releasing activity represents a larger molecular precursor with both $\mathrm{NH}_{2-}$ and $\mathrm{COOH}$-terminal additions, such as occurs with ACTH and its precursor (36).

There are several implications that may be drawn from the present results. The data extend the list of 
ectopic hormones that can be secreted by tumors derived from amine precursor uptake and decarboxylation-containing cells (38). From an evolutionary standpoint, it may be more than just coincidence that ectopic tumors that secrete hormones do so in clusters of interrelated peptides, i.e., ACTH and corticotropinreleasing factor (6), and GH-releasing activity, somatostatin, and GH (present report, 15, 19). The possibility is suggested that the genomes for a pituitary hormone and its hypothalamic releasing/inhibiting hormones may be closely related and that there may have been some evolutionary advantage to having the codons for controlling factors in close proximity to those for their target hormone.

From a clinical level there are at least four important considerations. First, the present results provide a basis for defining an "ecotopic GHRF syndrome" analogous to the ectopic ACTH syndrome $(6,7)$ and indicate that consideration should be given to the possible presence of an extrapituitary tumor in every patient with acromegaly. Second, they provide an explanation for the presence of $\mathrm{GH}$-secreting pituitary tumors in the multiple endocrine neoplasia syndrome, type I (pancreatic islet tumors, pituitary tumors, carcinoid tumors, parathyroid hyperplasia or tumors), and suggest the possibility that other relationships of this type will be uncovered with time. Third, the development of pituitary tumors as well as $\mathrm{GH}$ hypersecretion in patients with the ectopic GHRF syndrome indicates that prolonged stimulation by GHRF can cause tumor formation and provides strong evidence for the belief that GH-secreting pituitary tumors in at least some patients may be secondary to excessive secretion of hypothalamic GHRF. Finally, the results may help to explain the reports of GH-releasing activity in peripheral plasma from patients with acromegaly $(19,39$, 40 ). It is not unreasonable to predict that demonstration of circulating releasing activity may become an indicator of the ectopic GHRF syndrome. It would be expected that for a comparable degree of somatotrope stimulation, higher levels of GH-releasing activity would be present in peripheral circulation if the source were an extracranial tumor than if the GHRF originated from the hypothalamus and were released directly into the hypothalamic-pituitary-portal system.

\section{ACKNOWLEDGMENTS}

We gratefully acknowledge the excellent technical assistance of Narong Kovathana, Mary Cibelius, Rosemary Fitzer, and Rose Shaw. Materials for the pituitary hormone radioimmunoassays were provided by the National Institute of Arthritis, Metabolism, and Digestive Diseases, Pituitary Hormone Distribution Program.

This work was supported in part by U. S. Public Health Service grants AM 18722 and AM 19640 and a Career Development Award (Dr. Stachura) AM 00288.

\section{REFERENCES}

1. Hall, T. C. 1974. Paraneoplastic syndromes. Ann. N. Y. Acad. Sci. 230: 1-577.

2. Jones, J. E., S. R. Shane, E. Gilbert, and E. B. Flink. 1969. Cushing's syndrome induced by the ecotopic production of ACTH by a bronchial carcinoid. J. Clin. Endocrinol. Metab. 29: 1-5.

3. Pimstone, B. L., C. J. Uys, and L. Vogelpoel. 1972. Studies in a case of Cushing's syndrome due to ACTH-producing thymic tumor. Am. J. Med. 53: 521-528.

4. Schein, P. S., R. A. Delellis, C. R. Kahn, P. Gorden, and A. R. Kraft. 1973. Islet cell tumors. Current concepts in management. Ann. Intern. Med. 79: 239-257.

5. Liddle, G. W., J. R. Givens, W. E. Nicholson, and D. P. Island. 1965. The ectopic ACTH syndrome. Cancer Res. 25: 1057-1061.

6. Upton, G. V., and T. T. Amatruda, Jr. 1971. Evidence for the presence of tumor peptides with corticotropinreleasing-factor-like activity in the ectopic ACTH syndrome. N. Engl. J. Med. 285: 419-424.

7. Meador, C. K., G. W. Liddle, D. P. Island, W. E. Nicholson, C. P. Lucas, J. G. Nuckton, and J. A. Leutscher. 1962. Cause of Cushing's syndrome in patients with tumors arising from "non-endocrine" tissue. J. Clin. Endocrinol. Metab. 22: 693-703.

8. Greenberg, P. B., T. J. Martin, C. Beck, and H. G. Burger. 1972. Synthesis and release of human growth hormone from lung carcinoma in cell culture. Lancet. I: 350-352.

9. Faiman, C., J. A. Colwell, R. Ryan, J. M. Hershman, and T. W. Shields. 1967. Gonadotropin secretion from a bronchogenic carcinoma. Demonstration by radioimmunoassay. N. Engl. J. Med. 277: 1395-1399.

10. Schwartz, W. B., W. Bennett, E. S. Curelop, and F. C. Barrter. 1957. A syndrome of renal sodium loss and hyponatremia probably resulting from inappropriate secretion of antidiuretic hormone. Am. J. Med. 23: 529542 .

11. Shames, J. M., N. R. Dhurandhar, and W. G. Blackard. 1968. Insulin secreting bronchial carcinoid tumor with widespread metestases. Am. J. Med. 44: 632-637.

12. Southern, A. L. 1960. Functioning metastatic bronchial carcinoid with elevated levels of serum and cerebrospinal fluid serotonin and pituitary adenoma. J. Clin. Endocrinol. Metab. 20: 298-305.

13. Weiss, L., and M. Ingram. 1961. Adenomatoid bronchial tumors: a consideration of the carcinoid tumors and the salivary tumors of the bronchial tree. Cancer(Phila.). 14: $161-178$.

14. Buse, J., M. G. Buse, and W. J. Roberts. 1961. Eosinophilic adenoma of the pituitary and carcinoid tumors of the rectosigmoid area. J. Clin. Endocrinol. Metab. 21: 735-738.

15. Dabek, J. T. 1974. Bronchial carcinoid tumor with acromegaly in two patients. J. Clin. Endocrinol. Metab. 38: $329-333$.

16. Sonksen, P. H., A. B. Ayres, M. Braimbridge, B. Corrin, D. R. Davies, G. M. Jeremiah, S. W. Oaten, C. Lowry, and T. E. T. West. 1976. Acromegaly caused by bronchial carcinoid tumours. Clin. Endocrinol. 5: 503-513.

17. Caplan, R. H., L. Koob, R. M. Abellera, A. S. Pagliara, K. Kovacs, and R. V. Randall. 1978. Cure of acromegaly by operative removal of an islet cell tumor of the pancreas. Am. J. Med. 64: 874-882.

18. Zafar, M. S., R. C. Mellinger, G. Fine, M. Szabo, and L. A. Frohman. 1979. Acromegaly associated with a bronchial carcinoid tumor: evidence for ectopic production of growth hormone-releasing activity. J. Clin. Endocrinol. Metab. 44: 66-71. 
19. Leveston, S. A., Y. C. Lee, B. M. Jaffe, and W. H. Daughaday. 1978. Massive GH and ACTH hypersecretion associated with a metastatic carcinoid tumor. 60th Annual Meeting of The Endocrine Society, Boston, Mass. 341.

20. Szabo, M., and L. A. Frohman. 1975. Effect of porcine stalk median eminence and prostaglandin $\mathrm{E}_{2}$ on rat growth hormone secretion in vivo and their inhibition by somatostatin. Endocrinology. 96: 955-961.

21. Rick, J., M. Szabo, P. Payne, N. Kovathana, J. G. Cannon, and L. A. Frohman. 1979. Prolactin-suppressive effects of two aminotetralin analogs of dopamine: their use in characterization of the pituitary dopamine receptor. Endocrinology. 104: 1234-1242.

22. Frohman, L. A., and L. L. Bernardis. 1968. Growth hormone and insulin levels in weanling rats with ventromedial hypothalamic lesions. Endocrinology. 82: 11251132.

23. Szabo, M., and L. A. Frohman. 1976. Dissociation of prolactin-releasing activity from thyrotropin-releasing hormone in porcine stalk median eminence. Endocrinology. 98: $1451-1459$.

24. Stachura, M. E. 1976. Basal and dibutyryl cyclic AMPstimulated release of newly synthesized and stored growth hormone from perifused rat pituitaries. Endocrinology. 98: 580-589.

25. Lowry, O. H., N. J. Rosebrough, A. L. Farr, and P. J. Randall. 1951. Protein measurement with the Folin phenol reagent. J. Biol. Chem. 193: 265-275.

26. Undenfriend, S., S. Stein, P. Bohlen, W. Dairman, W. Leimgruber, and M. Weigele. 1972. Fluorescamine: a reagent for assay of amino acids, peptides, proteins and primary amines in the picomole range. Science (Wash.D.C.). 178: $871-872$.

27. Rivier, J. 1978. Use of trialkyl ammonium phosphate buffers in reverse phase HPLC for high resolution and high recovery of peptides and proteins. J. Liq. Chromat. 1: $343-366$.

28. Kronheim, S., M. Berelowitz, and B. L. Pimstone. 1976. A radioimmunoassay for growth hormone release-inhibiting hormone: method and quantitative tissue distribution. Clin. Endocrinol. 5: 619-630.

29. Marshall, J. C., R. A. Shakespear, W. D. Odell. 1976. LHRH-pituitary plasma membrane binding: the presence of specific binding sites in other tissues. Clin. Endocrinol. 5: $671-677$.

30. Szabo, M., M. Berelowitz, O. S. Pettengill, G. D. Sorenson, and L. A. Frohman. 1979. Somatostatin secretion by cultured human small cell carcinoma of the lung. 61st Annual Meeting of The Endocrine Society, Anaheim, Calif. 144.

31. Stachura, M. E., M. Szabo, and L. A. Frohman. 1978. Multiphasic effect of porcine stalk-median eminence extract on growth hormone release from perifused rat pituitaries. Endocrinology. 102: 1520-1526.

32. Stachura, M. E. 1976. Influence of synthetic somatostatin upon growth hormone release from perifused rat pituitaries. Endocrinology. 99: 678-683.

33. Stachura, M. E. 1977. Interaction of somatostatin inhibition and dibutyryl cyclic AMP on potassium stimulation of $\mathrm{GH}$ release from perifused rat pituitaries. Endocrinology. 101: 1044-1053.

34. Boyd, A. E., III, F. Sanchez-Franco, E. Spencer, Y. C. Patel, I. M. D. Jackson, and S. Reichlin. 1978. Characterization of hypophysiotropic hormones in porcine hypothalamic extracts. Endocrinology. 103: 1075-1083.

35. Nair, R. M. G., C. deVillier, M. Barnes, M. Antalis, and D. L. Wilbur. 1978. A bovine hypothalamic peptide possessing immunoreactive growth hormone-releasing activity. Endocrinology. 103: 112-120.

36. Herbert, E., J. Roberts, M. Phillips, R. Allen, M. Hinman, M. Budarf, P. Policastro, and P. Rosa. 1979. Biosynthesis, processing and release of corticotropin, $\beta$-endorphin, and melanocyte stimulating hormone in pituitary cell culture systems. In Frontiers in Neuroendocrinology. L. Martini and W. F. Ganong, editors. Raven Press, New York. In press.

37. Nakano, H., C. P. Fawcett, and S. M. McCann. 1976. Enzymatic dissociation and short-term culture of isolated rat anterior pituitary cells for studies on the control of hormone secretion. Endocrinology. 98: 278-288.

38. Pearse, A. G. E. 1977. The diffuse neuroendocrine system and the APUD concept: Related "endocrine" peptides in brain, intestine, pituitary, placenta, and anuran cutaneous glands. Med. Biol. 55: 115-125.

39. Stachura, M. E., L. A. Frohman, and A. P. S. Dhariwal. 1971. Effect of purified hypothalamic extract and acromegalic plasma on growth hormone synthesis and secretion in vitro. 53rd Annual Meeting of The Endocrine Society, San Francisco, Calif. A-81.

40. Hagen, T. C., A. M. Lawrence, and L. Kirsteins. 1971. In vitro release of monkey pituitary growth hormone by acromegalic plasma. J. Clin. Endocrinol. Metab. 33: $448-451$. 